\title{
DUKUNGAN KELUARGA DAN KOPING STRES PADA LANSIA YANG MENGALAMI MASALAH KESEHATAN FISIK DI SATU DESA PADA KABUPATEN LAMPUNG SELATAN
}

\author{
Merah Bangsawan*, Al Murhan*, Widodo* \\ Dosen Jurusan Keperawatan Poltekkes Tanjungkarang \\ Email : bangsawanmerahwawan@gmail.com
}

\begin{abstract}
Gangguan kesehatan yang dialami lansia menyebabkan stresor karena merasa menurunnya kesehatan menyebabkan lansia khawatir terhadap keselamatan jiwa, menjadi beban bagi keluarga karena harus mengurus dan merawat lansia ketika sakit serta menjadi beban bagi keluarga karena harus menanggung biaya pengobatan untuk membayar jasa medis saat berobat ke pelayanan kesehatan sehingga lansia merasa tidak berguna. Jumlah lansia di Kabupaten Lampung Selatan sebanyak 46.140 lansia, di mana jumlah laki-laki sebanyak 22.898 lansia dan perempuan sebanyak 23.242 lansia. Masalah kesehatan fisik banyak yang menderita penyakit seperti hipertensi, rhematoid artritis, gastritis dan influenza (Badan Pusat Statistik, 2014). Penelitian ini merupakan penelitian deskriptif dengan desain atau rancangan penelitian cross sectional yaitu ingin mengetahui hubungan antara dua variabel atau lebih yakni hubungan antara dukungan keluarga dengan koping stres pada lansia yang mengalami masalah kesehatan fisik di LKS. Al-Akhsan Desa Hajimena, Kabupaten Lampung Selatan Tahun 2016. Populasi dalam penelitian ini adalah seluruh lansia yang menjadi anggota LKS Al-Akhsan Desa Hajimena berdasarkan data dari pengurus LKS. Al-Ikhsan Desa Hajimena bulan Agustus 2016 yaitu sebanyak 80 orang lansia. Sampel penelitian ini adalah total populasi yang berarti seluruh populasi dalam penelitian dan dibatasi oleh kriteria inklusi sebanyak 58 orang lanjut usia. Hasil analisis dengan mengunakan uji chi square terdapat hubungan antara dukungan keluarga dengan koping stres pada lansia yang mengalami masalah kesehatan dengan $p$ value sebesar 0,000 . Dari hasil penelitian ini disarankan untuk dapat dilakukan penyuluhan terhadap responden dan masyarakat mengenai perlunya gukungan keluarga terhadap koping stres.
\end{abstract}

Kata Kunci: Dukungan Keluarga, Koping Stres, Lansia

\section{LATAR BELAKANG}

Lanjut usia (Lansia) merupakan kelompok umur yang rentan mengalami berbagai masalah yang kompleks baik gangguan masalah kesehatan akibat proses menua, menurunnya kemampuan kerja karena pensiun dan keterbatasan aktifitas fisik, akibatnya pendapatan keluarga menurun, kesepian ditinggal pasangan hidup dan anak-anak yang telah berkeluarga dan secara sosial interaksi dan peran lansia di masyarakat juga berkurang (Azizah, 2011).

Hasil Sensus Penduduk tahun 2010, Indonesia saat ini termasuk ke dalam lima besar negara dengan jumlah penduduk lanjut usia terbanyak di dunia yakni 18,1 juta jiwa atau 9,6\% dari jumlah penduduk. Berdasarkan proyeksi Bappenas, jumlah penduduk lansia 60 tahun atau lebih diperkirakan akan meningkat dari 18,1 juta (2010) menjadi 29,1 juta (2020) dan 36 juta (2025), (Depkes,RI,2012).

Proses menua yang dialami lansia menyebabkan lansia rentan mengalami berbagai macam penyakit degenerative, karena berkurangnya kemampuan jaringan dan organ tubuh lansia untuk memperbaiki diri serta mengganti dan mempertahankan fungsi normalnya, daya tahan tubuh yang menurun menyebabkan lansia tidak memiliki anti body yang baik untuk mempertahankan diri dari invasi kuman, bakteri maupun virus yang dapat merusak organ dan jaringan tubuh. Hal inilah yang menyebabkan lanjut usia mengalami masalah psikologis yang banyak mempengaruhi kesehatan psikis, sehingga menyebabkan orang lanjut usia mudah 
mengalami stres karena gangguan kesehatan merupakan salah satu stresor yang sering dialami lanjut usia (Depkes,RI,2012).

Gangguan mental emosional merupakan suatu keadaan yang mengindikasikan individu mengalami suatu perubahan emosional akibat stresor yang dapat berkembang menjadi keadaan patologis apabila terus berlanjut. Hasil survei Badan Pusat Statistik, jumlah lansia sebanyak 46,140 lansia, di mana jumlah laki laki sebanyak 22.898 lansia dan perempuan sebanyak 23.242 lansia. Masalah kesehatan fisik banyak yang menderita penyakit seperti hipertensi, rhematoid artritis, gastritis dan influenza (Badan Pusat Statistik, 2014).

Stres yang dialami lansia, karena gangguan kesehatan fisik perlu dukungan keluarga dalam bentuk komunikasi keluarga yang fungsional agar lansia merasa diperhatikan secara emosional, hal ini dapat menjadi mekanisme pertahanan diri untuk mengelola stres akibat gangguan kesehatan fisik yang disebut koping karena kehadirannya dalam keluarga masih dibutuhkan sehingga lansia lebih tenang dalam menghadapi gangguan masalah kesehatan (Maulana, 2012).

Seluruh lansia yang tergabung dalam pembinaan Lembaga Kesejahteraan Sosial (LKS) Al-Ikhsan Desa Hajimena yang berjumlah 51 orang menunjukan bahwa beberapa lansia mengalami gangguan masalah kesehatan fisik, di antaranya adalah lansia mengalami tekanan darah rendah adalah 2 lansia, tekanan darah tinggi 24 lansia, resiko $\mathrm{DM}>=6 \mathrm{mg} / \mathrm{dl} 2$ lansia, dan penyakit lain seperti rhematoid artritis dan gout sebanyak 27 lansia (Data hasil Pengabmas, Dosen Jurusan Keperawatan, 2015).

\section{METODE}

Penelitian ini merupakan penelitian deskriptif dengan desain atau rancangan penelitian cross sectional yaitu ingin mengetahui hubungan antara dua variabel atau lebih yakni hubungan antara dukungan keluarga dengan koping stres pada lansia yang mengalami masalah kesehatan fisik. Populasi dalam penelitian ini adalah seluruh lansia yang menjadi anggota LKS Al-Ikhsan Desa Hajimena sebanyak 58 orang lansia. Sampel penelitian ini adalah total.

Variabel penelitian terdiri dari dukungan keluarga dan koping stress. Pengumpul data dukungan keluarga dan koping stress dilakukan dengan lembar kuesioner. Teknik pengumpulan data dukungan keluarga dan koping stres pada lansia yang mengalami masalah kesehatan fisik, data langsung dikumpulkan pada hari yang sama pada saat penelitian.

Data yang terkumpul selanjutnya diolah dan dianalisis secara univariat dan bivariat. Analisis univariat bertujuan untuk mendeskripsikan karakteristik setiap variabel penelitian. Hasil analisis univariat menghasilkan distribusi frekuensi dan persentase dari tiap variabel. Analisis univariat dalam penelitian ini menyajikan persentase dari dukungan keluarga dan koping stres lansia dalam menghadapi masalah kesehatan fisik. Analisis bivariat dilakukan dengan uji Chi Square yang bertujuan untuk menguji hubungan variabel dukungan keluarga dan variabel koping stress. Taraf kesalahan yang digunakan adalah 5\%, untuk melihat hasil kemaknaan perhitungan statistik digunakan batas kemaknaan 0,05 . Jika $p$ value $\leq 0,05$ maka hasilnya bermakna yang artinya Ho ditolak dan Ha diterima.

\section{HASIL}

\section{Analisis Univariat}

Tabel 1: Distribusi Frekuensi Berdasarkan Dukungan Keluarga pada Lansia yang Mengalami Masalah Kesehatan Fisik

\begin{tabular}{lcc}
\hline \multicolumn{1}{c}{ Dukungan Keluarga } & f & $\%$ \\
\hline Kurang Baik & 15 & 25,9 \\
\hline Baik & 43 & 74,1 \\
\hline Jumlah & 58 & 100 \\
\hline
\end{tabular}


Tabel di atas menggambarkan bahwa dukungan keluarga yang baik sebesar 74,1 $\%$, hal ini berarti bahwa sebagian besar keluarga mendukung responden yang mengalami masalah kesehatan fisik.

Tabel 2: Distribusi Frekuensi Berdasarkan Koping Stres pada Lansia yang Mengalami Masalah Kesehatan Fisik

\begin{tabular}{lcc}
\hline \multicolumn{1}{c}{ Koping Stres } & f & $\%$ \\
\hline Mal Adaptif & 19 & 32,8 \\
\hline Adaptif & 39 & 67,2 \\
\hline Jumlah & 58 & 100 \\
\hline
\end{tabular}

Tabel di atas menggambarkan bahwa koping stres responden terhadap yang baik sebesar $67,2 \%$, hal ini berarti bahwa sebagian besar keluarga mendukung responden dalam kehidupan sehari hari yang berkaitan dengan koping stres responden yang mengalami masalah kesehatan fisik.

\section{Analisis Bivariat}

Tabel 3: Hubungan Dukungan Keluarga dengan Koping Stress pada Lansia yang Mengalami Masalah Kesehatan Fisik

\begin{tabular}{lccc}
\hline \multirow{2}{*}{$\begin{array}{c}\text { Dukungan } \\
\text { Keluarga }\end{array}$} & \multicolumn{2}{c}{ Koping stress } & \multirow{2}{*}{ Total } \\
\cline { 2 - 3 } & Mal Adaptif & Adaptif & \\
\hline Kurang Baik & 14 & 1 & 15 \\
\hline Baik & 5 & 38 & 43 \\
\hline Jumlah & 19 & 39 & 58 \\
\hline$p$ value $=0.000$ & & &
\end{tabular}

Tabel di atas menggambarkan bahwa dari 58 responden yang mendapat dukungan keluarga baik memiliki koping stress yang adaptif yaitu sebesar 38 responden atau $65,5 \%$ dengan $p$ value $=$ 0,000 , yang berarti ada hubungan antara dukungan keluarga dengan koping stress pada lansia yang mengalami masalah kesehatan fisik.

\section{PEMBAHASAN}

Berdasarkan hasil penelitian yang dilakukan di LKS Al-Aksan Hajimena Kecamatan Natar Lampung Selatan, karakteristik responden sebanyak 58 orang berdasarkan usia, bahwa rata rata responden 37 orang $(63,86 \%)$ dengan usia termuda 60 tahun dan usia tertua 78 tahun dan responden 21 orang $(36,20 \%)$ dengan usia dibawah 60 tahun. Hal ini berarti responden dalam penelitian ini termasuk dalam kategori lansia sesuai dengan UU No 13 Tahun 1998 tentang kesejahteraan lansia yang berbunyi sebagai berikut Lansia adalah seseorang yang telah mencapai usia 60 tahun keatas (Azizah, 2011)

Hasil penelitian yang telah dilakukan terdapat $74,1 \%$ dukungan keluarga baik dan dukungan keluarga kurang baik sebesar 25,9\%. Sedangkan koping stres yang adaptif sebesar 67,2 \% dan koping stres mal adaftif sebesar 32,8\%.

Berdasarkan hasil analisis yang dilakukan terhadap 58 responden, didapatkan $74,1 \%$ responden yang mendapat dukungan keluarga baik memiliki koping stres yang baik pula yaitu sebesar $65,5 \%$. Sedangkan responden yang mendapat dukungan keluarga kurang baik sebesar 25,9\% memiliki koping stres mal adaptif yaitu sebesar 24,1\%. Hal ini berarti ada hubungan antara dukungan keluarga dengan koping stres pada lansia. Berdasarkan hasil uji chi square pada $\alpha=$ 0,05 didapatkan nilai $x^{2}=33,70, p=0,000$. Berarti terdapat hubungan yang signifikan antara dukungan keluarga dengan koping stres pada lansia yang mengalami gangguan fisik di LKS Al Aksan Desa Hajimena Kecamatan Natar Lampung Selatan $\mathrm{P}(0,000)<\alpha(0,05)$. Hal ini sejalan dengan penelitian yang dilakukan oleh Pande Yasa (2014) di peroleh data 40 responden dengan dukungan keluarga kurang mengalami mengalami kemungkinan depresi sebanyak 1 orang $(5,3 \%)$, responden dengan dukungan keluarga kurang mengalami depresi sebanyak 18 orang $(94,7 \%)$, responden dengan dukungan keluarga kategori sedang 
yang kemungkinan mengalami depresi sebanyak 17 orang (81\%), dan responden dengan dukungan keluarga kategori sedang yang mengalami depresi sebanyak 4 orang (19\%). Berdasarkan hasil uji chi square pada $\alpha=0,05$ didapatkan nilai $\mathrm{x}^{2}=23,09$, $\mathrm{p}=0,001$. Berarti terdapat hubungan yang signifikan antara dukungan keluarga terhadap kejadian depresi pada lansia di Desa Parerenan Mangwi Badung. $P$ $(0,001)<\alpha(0,05)$. Hasil penelitian yang dilakukan oleh Dewi Kristyaningsih (2011) diperoleh data 96 responden yang mendapat dukungan keluarga diantaranya dukungan kurang (7\%), sedang (12\%), baik $(81 \%)$. Sedangkan responden yang mengalami depresi diantaranya lansia tidak mengalami depresi (79\%), mengalami depresi ringan (10\%), depresi sedang (5\%) dan depresi berat (6\%). Berdasarkan hasil analisa menggunakan uji korelasi Spearman Rank (Rho) di peroleh $\rho=0,000$ $<\alpha=0,05$ berarti terdapat hubungan antara dukungan keluarga dengan tingkat depresi pada lansia di Desa Langsar Laok Kecamatan Saronggi Kabupaten Sumenep.

Hal ini sesuai juga dengan teori peran keluarga dalam merawat lansia (Galuh, 2012) antara lain :

a. Menjaga dan merawat kondisi fisik anggota keluarga yang lanjut usia, tetap dalam keadaan optimal atau produktif.

b. Mempertahankan dan meningkatkan status mental pada lansia.

c. Mengantisipasi adanya perubahan sosial dan ekonomi pada lansia.

d. Memotivasi dan memfasilitasi lansia untuk memenuhi kebutuhan spiritual, dengan demikian meningkatkan ketakwaan lansia kepada Tuhan YME.

\section{KESIMPULAN}

Penelitian ini menyimpulkan bahwa sebagian besar lansia yang mengalami masalah kesehatan fisik mendapatkan dukungan keluarga secara baik dan mekanisme koping stressnya sebagian besar adaptif. Selanjutnya berdasarkan uji ststistik disimpulkan bahwa ada hubungan antara dukungan keluarga dengan koping stres pada lansia yang mengalami masalah kesehatan fisik di LKS Al-Ikhsan Desa Hajimena, Kabupaten Lampung Selatan.

Berdasarkan kesimpulan penulis menyarankan pihak Puskesmas di Wilayah Hajimena untuk melakukan penyuluhan kesehatan masyarakat sebagai penatalaksanaan responden yang memiliki koping stres mal adaptif serta menjalin kerja sama dengan intitusi pendidikan untuk melakukan kegiatan pengabdian masyarakat dan praktik lapangan bagi mahasiswa agar dapat mengaplikasikan ilmu bagi kesehatan masyarakat.

\section{DAFTAR PUSTAKA}

Azizah Ma'rifatul Lilik, 2011. Keperawatan Lanjut Usia. Yogyakarta : Graha Ilmu

Maulana, 2012, Hubungan Komunikasi Keluarga Dengan Koping Stres Lansia Dalam Menghadapimasalah Kesehatan Fisikdiwilayah Kerja Puskesmas Bernung. Bandar Lampung : Fakultas Kedokteran Universitas Malahayati.

Departemen Kesehatan Republik Indonesia, 2012. Sehat Dan Aktif Diusia Lanjut . dalam http://www.depkes.go.id di akses tanggal 15 April 2016.

Yasa Pande, 2014, Hubungan Dukungan Keluarga Terhadap Kejadian Depresi Pada Lansia di Desa Parerenan Mengwi Badung. Mengwi Badung: STIKES Bina Usada Bali dalam diakses tanggal 27 April 2016. 